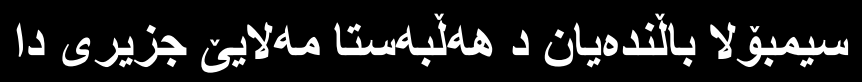

\section{SEMBOLA BALINDEYAN DI HELBESTA MELAYÊ CIZÎRÎ DA}

\author{
Fakhir Alî Arif ${ }^{1}$ \\ فاخر على عارف
}

\section{هوخته}

سيمبوّل و هيّما و ميسال بايهييّ سهردكهيى ئهدهبيياتا سوّفيكهرييّ بِيّك دئينن، زبهر كو د نهرين

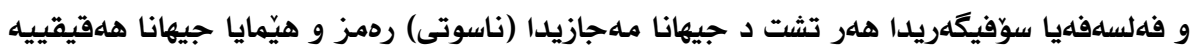

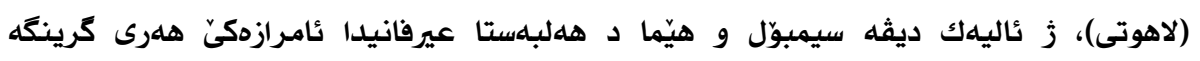

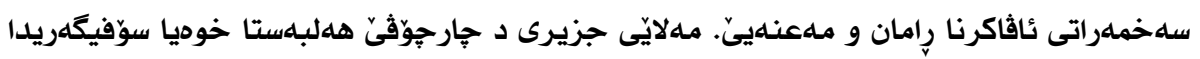

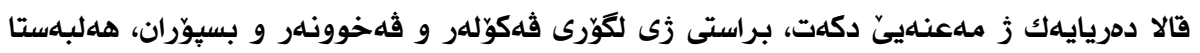

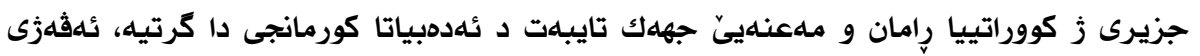

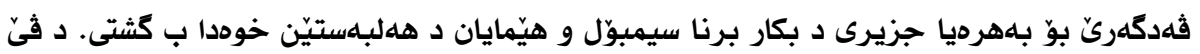

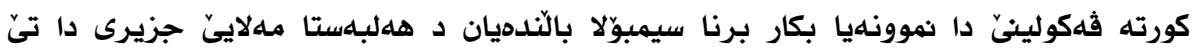

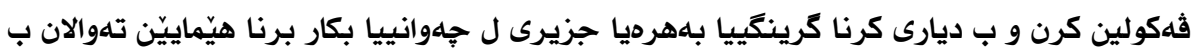

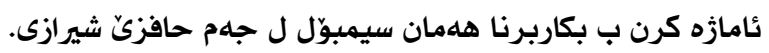

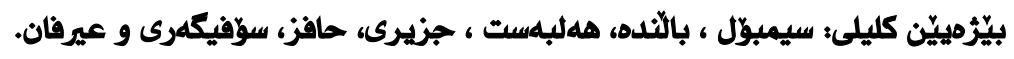




\title{
Melayê Cizîrî’nin Şiirlerinde Kuş Sembolü
}

\section{ÖZ}

Sembol, imaj ve benzetme tasavvuf edebiyatında önemli bir yer tutar. Tasavvuf edebiyatında mecazi (nasuti) olan her şey aslında hakiki (lahuti) olan şeylerin imgesi ve remzi olduğu için sembol ve imaj irfani şiirde anlamı inşa etmede en önemli araçlardandır. Melayê Cizîrî'nin tasavvufi şiiri de derin anlamlar yüklüdür. Gerçekten de araştırmacılar ve konunun uzmanlarına göre Cizîrî'nin şiiri fikir ve anlam derinliği bakımından Kürt edebiyatında önemli bir yer tutar. Bu da Cizîrî’nin sembol ve imajları kullanmadaki becerisinin bir göstergesidir. Bu çalışmada Cizîrî’nin "kuş" sembolünü kullanma biçimi incelenmektedir. Ayrıca Cizîrî'nin hayvan sembollerini kullanma biçimi Hafiz-i Şirazi'nin aynı sembolleri kullanma biçimi ile karşılaştırılarak sunulmuştur.

Anahtar Kelimeler: Sembol, Kuş, Şiir, Cizîrî, Hafiz, Tasavvuf, İrfan

\section{Bird Symbols in Molla al-Jezeri’s Poetry}

\begin{abstract}
Symbol and image take an important place in Sufism literature. Since everything that is figurative (nasuti) in Sufism literature is actually the symbol of the things that are real (lahuti), the symbol is one of the most important tools in building meaning in poetry. The Sufi poetry of Molla al-Jezeri is also loaded with deep meanings. Indeed, according to researchers and experts, the poem of al-Jezeri has an important place in Kurdish literature in terms of depth of idea and meaning. This is an indicator of al-Jezeri ability to use symbols. In this study, Jezeri's way of using the "bird" symbol is examined. In addition, the way that Jezeri used animal symbols was compared with the way Hafez Shirazi used the same symbols.
\end{abstract}

Keywords: Symbol, Bird, Poetry, Jezeri, Hafez, Sufism.
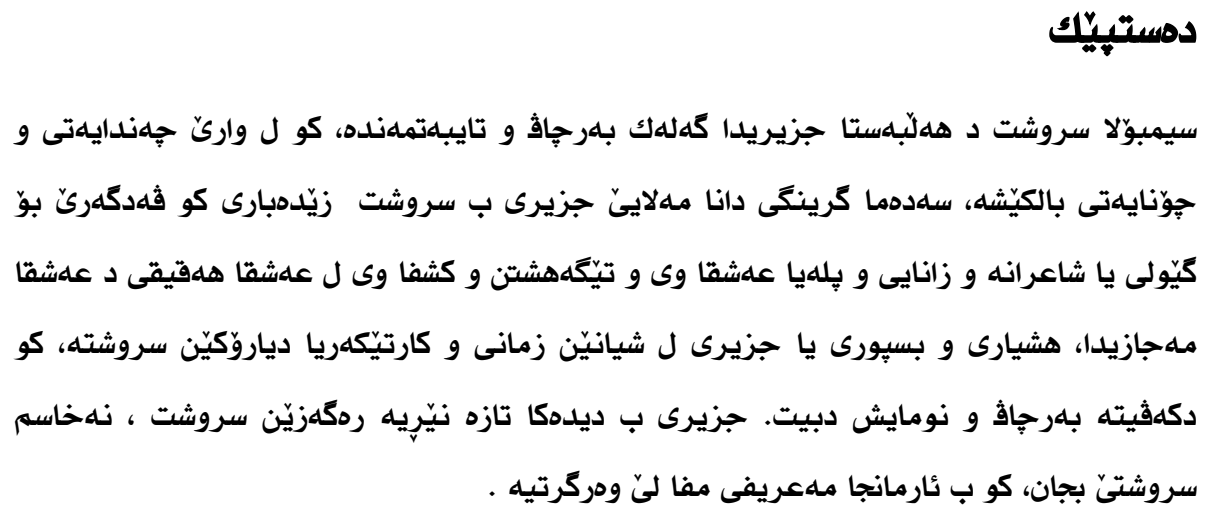


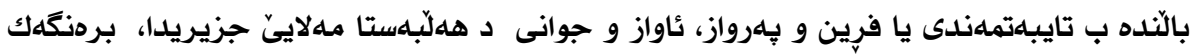

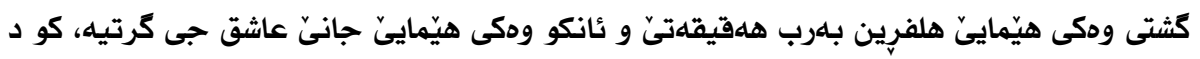
جوريّن خوهدا هاتيه كَريّدان ب ريّسا و شيّوازيّ ئهدهبا سوّفيكهرى نهخاسم ل واريَّ زمانفه،.

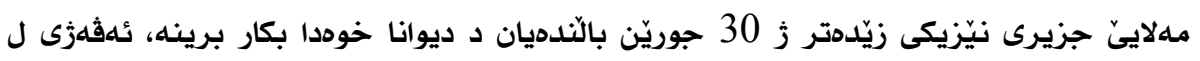

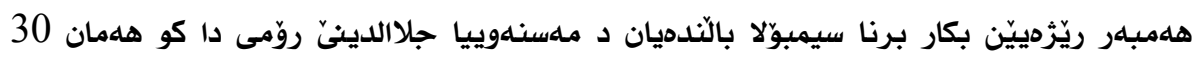
بالَّدهنه ، هيّزو شيانيّن جزيرى ل ئاستى عيرفانى و ئهددبى و بلههرديى نيشان دده، للهوما كَهلهك

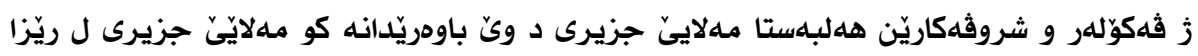

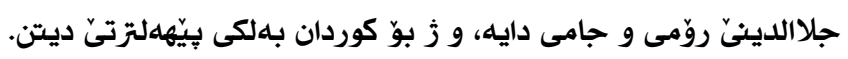

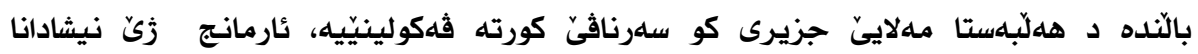

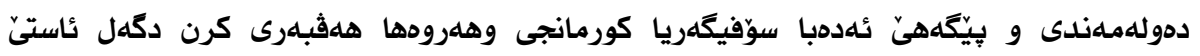

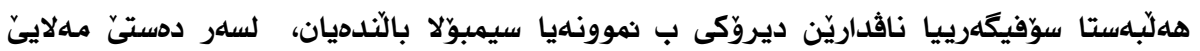

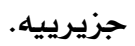
ئهذ كورته ڤهكولينه خوه د كرينكيهك تايبهتدا دبينى، ئهو زى نيشادانا بههرهو شيّوازيّ مدلايى جزيرى ل بكاربرنا هيّمايا بالَندديان د هلبلهستيّن خوددا ب ئاوايهكى كو نووكارى و بهرفرديى

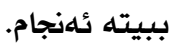

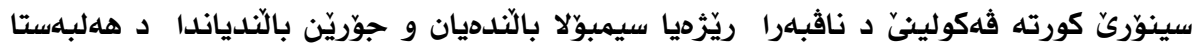

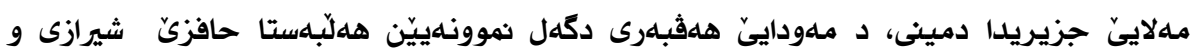
جلاالدين روّمى و فريدالدين عهتار.

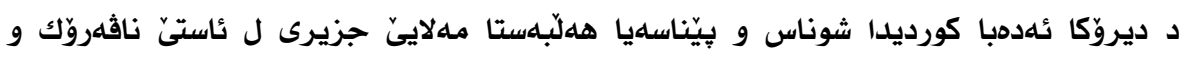

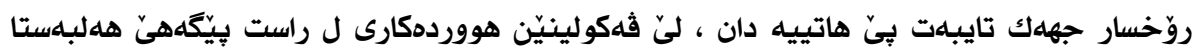

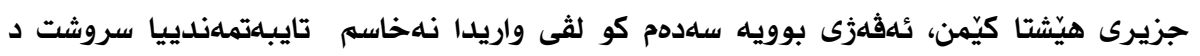
هلبلهستا جزيرى جافكانى كَهلهك كيّم بن، ئهفهزى ئاستهنكيهك سهرهكى بوو. كورته ثهكولين كَّرى ريّبازا وهسفى شيكارى و هلهبهريى هاتيه ئهنجامدان، كوخوه د دوو تلهوهرانادا دبينى، يا يلكى كورتيهك لسهر بِيّناسهيا سيمبوّل و دياركرنا سيمبوّل د هلبلهستيّن سوّفيكهريدا و هلروهها سيمبوّلى بالّندهيان د ئهدهبا عيرفانيدا، يا دوويان زى ب ردنكهك سهردكى رووناهى ئيّخستنه سلهر سيمبوّلا بالَندهيان د هلَّبهستا جزيريدا، كو د تهوهريّ براكتيكى دا هلول

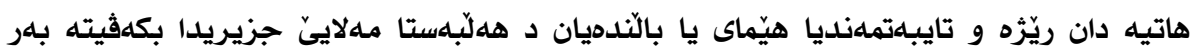




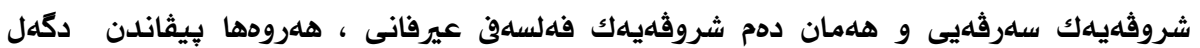
هللّبهستفان و عارفيّن نافدار وهكى شيّخ فريدالدين عهتار و جلال الدين روّمى و د سلهريدا

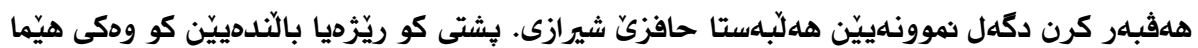
و سيمبوّل د هللبهستا جزيريدا هاتينه ديار كرن، تلنى 7 هلهفت جوّر ل وان بالَّدهيان وهكى نموونه هاتنه شروّثه كرن، ئهو زى ب سلددما قهبارهيا كورته فهكوليني.

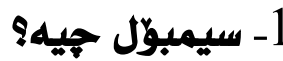

سيمبوّل ب كوردى هيّما، نيشان و جلههنت دهيّته كَوّتن، كو ب علردبى دبيته ردمز و ب فارسى نماد و ب زمانى ئنكليزى و فرهنسى هلمان Symbol هاتييه، پِهيڤا سيمبوّل ز لاتينى

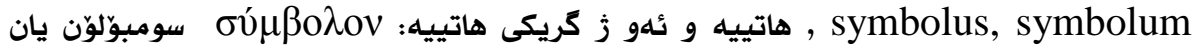

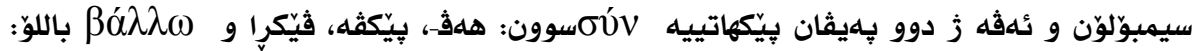
هاثَّرَتن، دانان. بوّ نيشان و دروو بكاردهات(

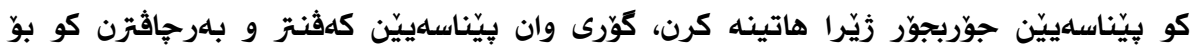

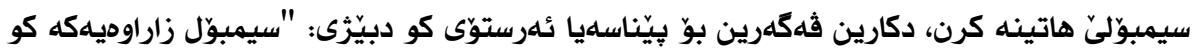

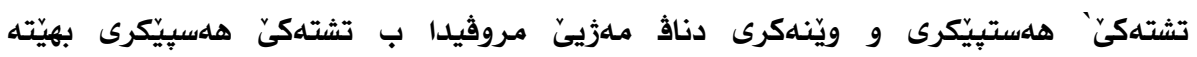

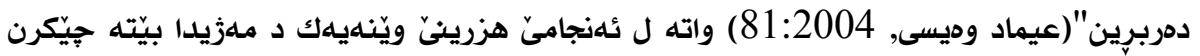

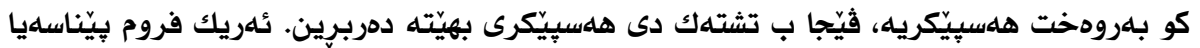

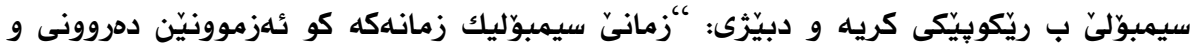

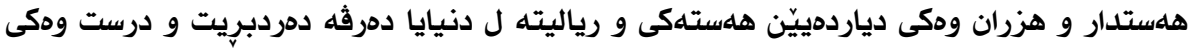

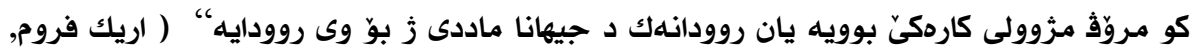

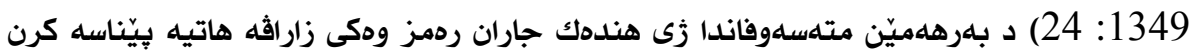

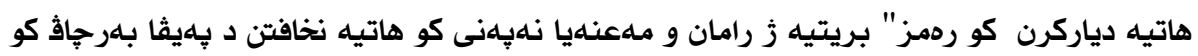

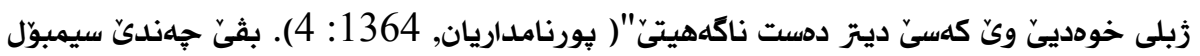

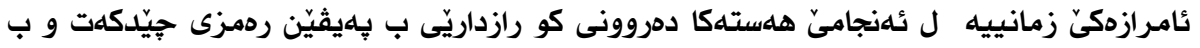

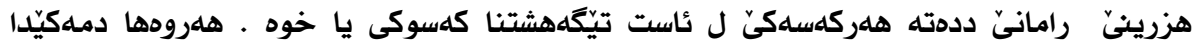

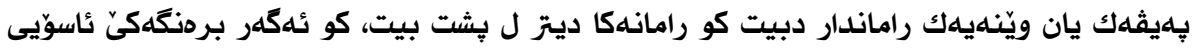

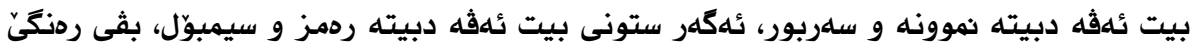

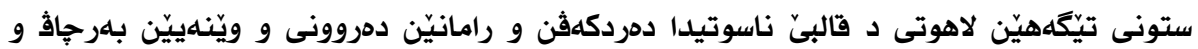
هلمستدار دهيّنه نيشان دان. 


\section{2- سيمبوّل د هلبلبستيّن سوّفيزمى دا}

سيمبوّل د زمانيّ سوّفيزميّدا ريّرِودوكا ب هلكشان و داكيّشان هليه و مدرتهبهكيّ ل بوونيّ، كو

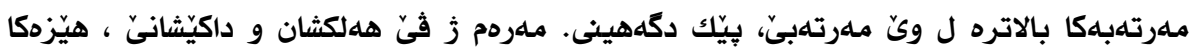

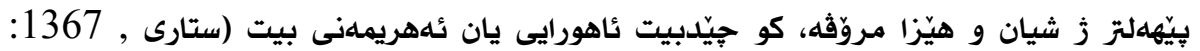

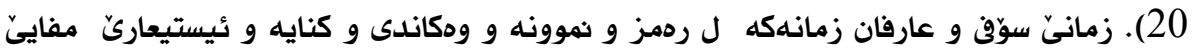
وهردكَرى و تيّكَهشتن ل فى زمانيّ سوّفيزمى هاتيه كريّدان ب كشف و شروڤهيا وان رهمز و سيمبوّلان كو بيى هاتيه دهربرين و نفيسين. زمانيّ هلبلهستا سوّفيكهرى د بنهتكاردا زمانهكيّ دمروونى يان رازدار و نـزهلاله .

د بلرهلميّن سوّفياندا جوره جوانيهكا ثهشارتى هليه كو ز ئدنجامي ڤههاندنهكا جلفهنكى شيّوازهكيّ تايبهت ليّ جِيّدبيت و دهما خوهندثان دخوونى هلست ب تام و خوشيى دكهت و و هلبلهستي لدووث تيّكَهشتنا خوه شروڤه دكهت ، لهوما هلتا نووكهزى بلهرهلميّن هوزانثانيّن

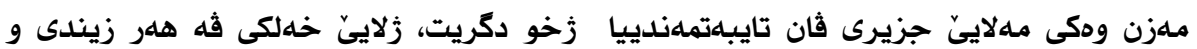

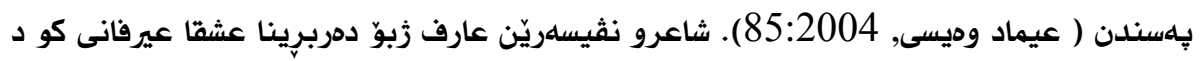

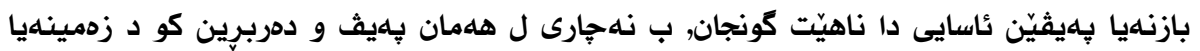

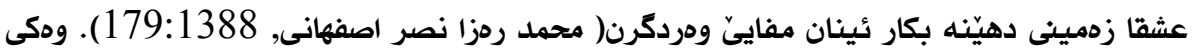

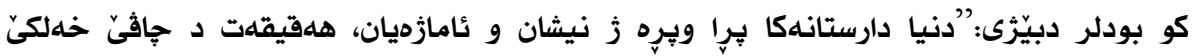

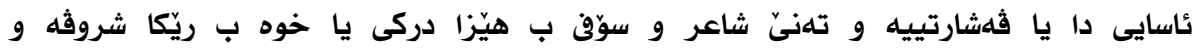

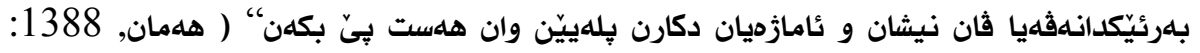

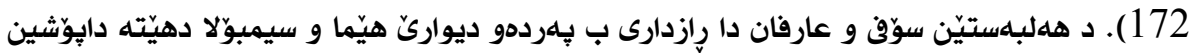

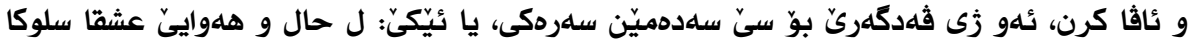

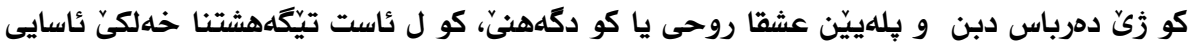

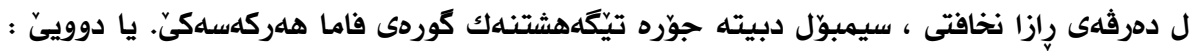

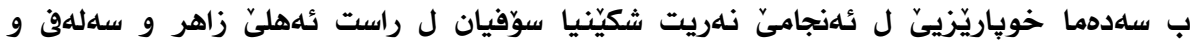

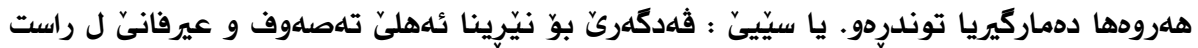

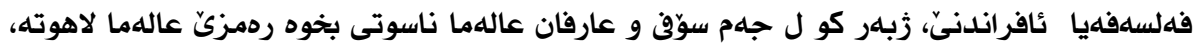
يانى هلرتشت و هلر ئافرهنده رهمز و هيّمانه بوّ عالهما ئافريّنهر. 


\section{3- سيمبوّلا بالَّلدهيان د بهرهميّن عارفاندا}

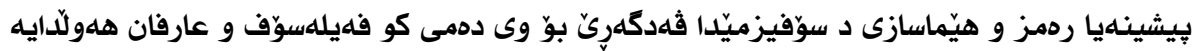
روحئ (جان) وهكى بالّنده تايببهت د سيمبوّلا" كهثوك (كوتر) و باز " نيشان بدهن ( هلهمان, 1388: 180). سلهرنجدان ب دياروك و دهركهفتنيّن وهكى ردكَّزيّن سروشتى و هلهر تشتهكيّ يان

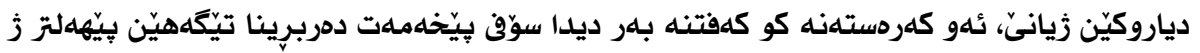
هلستان، بالَّده ئهو دهركهفتنن كو كَلهك بالا عارف و سوّفيان كشاندييه، زبهر كو بالَّده خودانى

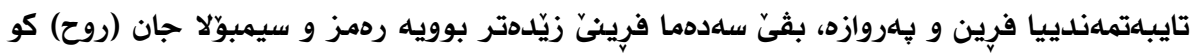
ل كهلهخى دهردكهفيت و بهر ب ههقيقهتا خو دفريت ( شواليه, 1387: 200). كونجانا ردوش و تايبهتمهندييا سروشتى يا بالّندهيان دكَهل مروّة و سالكيّن ريّيا هدقيقهتى بوويه سهدهما ويّ كو

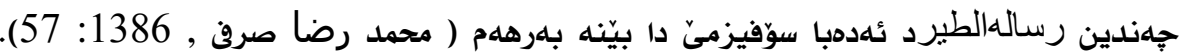
ودكى رسالة|لطير يا ابوعلى سينا(980م-1037م) ، رسالة الطير يا ابوحامد محمد غزالى

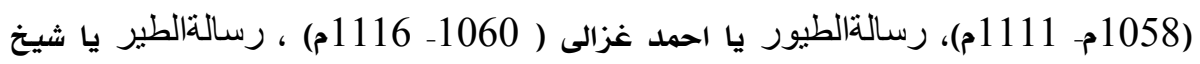
اشراق سوهردوهردى (1154- 1191م) ، منطق الطير يا شيّخ عطار( 1142- 1221م) هلروهها كَرينكى يا سيمبوّلا بالّنديان د هلبلهستيّن حهكيم سنائى غهزنهوى( 1080-ـ 1141م) ، جلال الدين محمد رومى ( 1207- 1273م) ، حافزيّ شيرازى ( 1326- 1221م) ، مهلايئ جزيرى (1565ـ 1640م) دهرباسى قوناغهك بهرفره و تازه دبيت.

\section{4- سيمبوّلا بالَّدهيان د هلبلهستا مهلايئ جزيرى دا}

مهلايئ جزيرى د ههلبهستيّن خوددا دهريايهك ز راز و مهعنهيان ب سيمبوّل و رهمز و هيّمايان

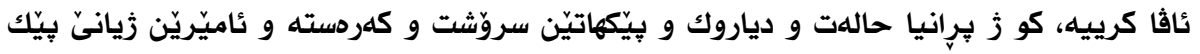

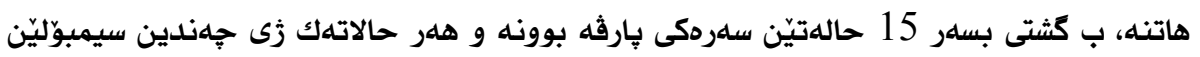

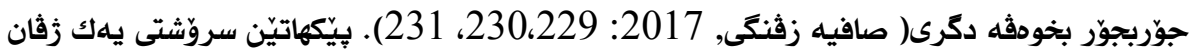

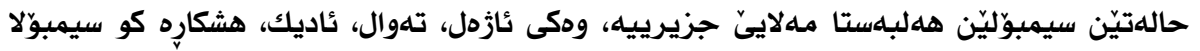
تهوالان يهك ز سيمبوّل و هيّمايا بلهرجاڤه د هلبلهستا مهلايّي جزيريدا( هلمان: 94). زبهركو فوّلكلور و كلتورا كورددوارى يهك ز جافكانييا ردوشهنبيرييا جزيرييه (شعبان جالى, 2008

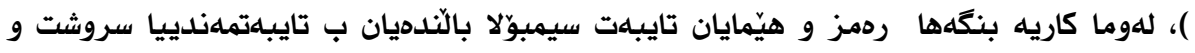
كلتور و فوّلكلورا كوردى دهولهمهند بكهت و تهنى كاريكهرى بسهر تيّرامانا فهلسهفييا عيرافانى يا مهلاييّ جزيرى بكهت. ئهو زى بكاربرنا لايهنى جوانى و ئهريّنى د هلر سيمبوّلهكا بالَّدديان، 
دهمى كو هلمان تايبهتمهندى د ريّسايا هيّمايا عيرفانيا كو باندوّر هلبوويه لسهر شيّوازيّ جزيرى ناهيّ ديتن، تايبهت نُهددبياتا سوّفيكهريا فارسى(هلمان ، 80:2008) . ب كشتى مهلايّيّ جزيرى ل واريّ جهندايلهى و جوّنايهتيدا دكارين بيّزَين وهرجهرخان كرينه، تايبهت دهما دكَّل ئهددبياتا سوّفيكهرى يا فارسى مينا سلنايى ، علتار، روّمى و تايبهت حافزيّ شيرازى بهّ هلهبهر كرن ، كو مهلايى جزيرى زيّدهى هلهر ئهديب و عارفهك دى ييّن فارس دبن كارتيّكهرى يا هلبلهستا حافزيّ

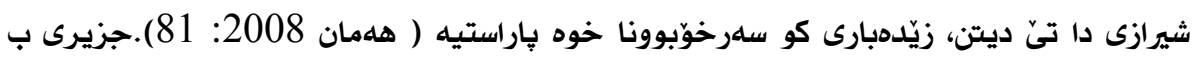

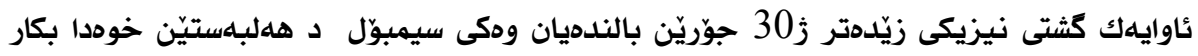

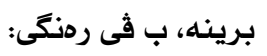

عهنقا( سيمهرخ): 2 حاران/ هوما : 3 جاران/ هودهود: 9 ج / مورغ: 1 ج/ عهندهليب: 4 ج / كَّيين : 5ج / تووتاك :2ج / تاووس: 1 ج / طوطي: 3 ج / تهيرك: 4 ج / بولبول: 26 ج / باز: 5ج / تهيهو: 1ج / شاهين: 4ج / تهيغون: 2ج / كبك ( كلو): 1ج / تهزرو: 1ج / دوراج

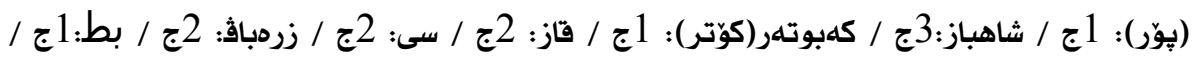

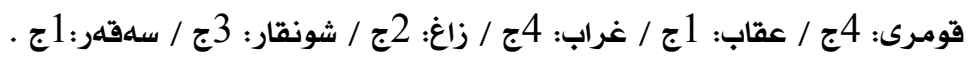

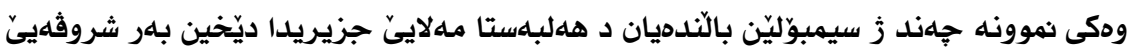

\section{4}

عنقا نافيّ بالندديهكي خيالى و رهمزييه كو د منطق الطير يا فريدالدين عهتتار دا ب رهمزو هيمايا بالاترين بلهيا روحى يا سالكيّ سلوكا ريّبازا عيرفانيّيه ، كو ب فارسى دبيّزَنيّ سيمرغ (فريدالدين علتتار: 32 ). بكوردى زى ( سيملرخ ) دبيّزَن. علنقا يانى سيمرغ هلمان " سئين مرو" كو د ئاثيّستاييّ دا هاتيه واته ميرىّ بالندديان، (فاطمه مودرسى, 194:1397). سيملرخ د د

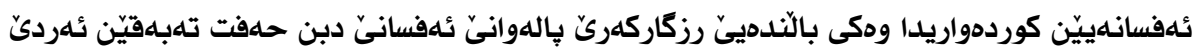
هاتيه دياركرن. د تيّكستيّن عيرفانيدا ودكى بوونهكا نهديار و بئ نيشان و ب برإنى كنايهيه بوّ

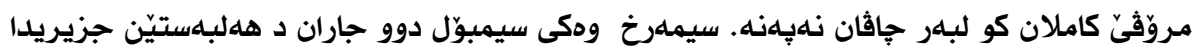

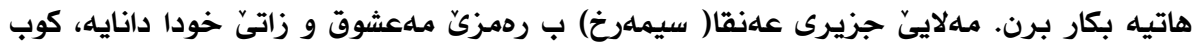

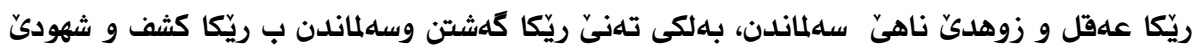
دبيت. تيّكَّتن لثى واريڤه مـلاييّ جزيرى نهرينهك مينا حافزيّ شيرازى و جلالدين روّمى هليه 


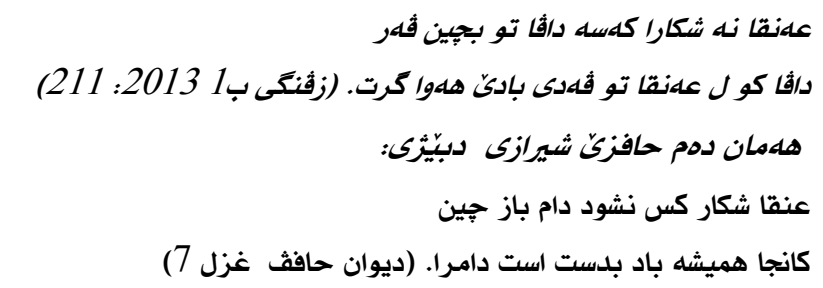

يانى عهنقا نكارى ببيته راثا كهس ب خهرٍك و داثان زبلى با و هلوا تشتهك دى ناهيّته كَرتن.

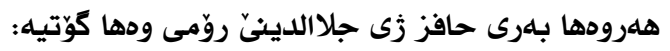

عنقا كه يابد دام كس در بيش ان عنقا مكسل

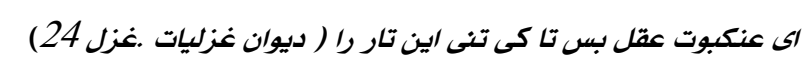

مهلايئ جزيرى د قهسيدهيهكا ديتز دا ديسان عهنقا ودكى ردمزيّ مهعشوق و مهحبوب وئيرادميا زاتى خودا نيشاندايه، كودهما دل و دهروون ز هلواو هلوهسان تئ پِاقزّ كرن، ويّ مهحبوب تيّدا جى بكره و ئيدى نه هلوجلددارى كَريانه لدووڤدا ل نئسمانان (هلرزار,1361: 124), هلهروسا هنكى خودا بخوه وب ئيرادهيا خوه دنيشته ناقا دل و نه هلوجلدارى فرين و بِروازانه ل ناسمانان، بهلكى جهى زاتى هلى ناثَ دلدايه، وهكى كو دبيّزَى: -

كُورى مهلا عبدوسهلامئ جزيرى جِيّدبى مهلاى ل فهرمودهيا كو دبيّزَى: (ما وسعني سمائي و لا ارضي، بل وسعني قلب عبدي المؤمن ) ئيلهام ومركرتبى.(عبدالسلام جزيرى, 2004 :

\section{Lوم-2.4}

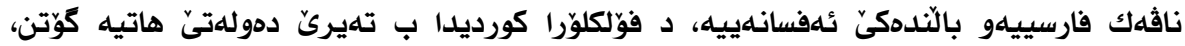
سيّبهرا وى سلدهما خوّش ئيقبالى و موراد حاسلييه.(محمدئهمين دوّسكى,2007: 638) دـ ئهدهبياتا عيرفانيدا ب رهمزهك كَتى بوّ سهروهرى، بهختهوهرى، خوّش ئيقبالى ، لايقى ، ليّهاتى و مدرتهبه هاتييه نيشان كرن، د باوهريّن ديّريندا ئهذ بالَندهيه هلستى(ئيسك) خور و ج بونهوهران

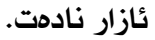
د هلبستيّن مللاييّ جزيرى دا سيى جاران نافيّ هوما هاتيه، كو ب نيشانى سيّبهرا تهناهييّ وموراد حاسلى و ئافردندييا قودردتى ب بِهر و باليّن هوماى ودسفانديه ودكى دبيّزَى: 


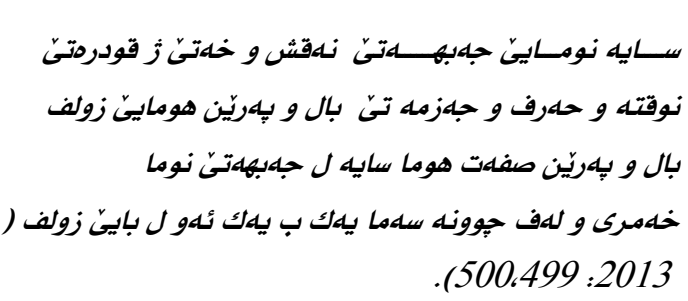

حافزيّ شيرازى كو د غهزهليّن ويدا بوّ 7 جاران نافى (هما ) تيّ ديتن ب هلمان بهختهوهرى و سلروهرى و خوّش ئيقبالى و ليّهاتى وسفاندى و رهمزانديه ودكى دبيّزَى: هماى اوج سعادت بـه دام ما افتد اكر تورا كَوزرى بر مقام ما افتد ( ديوان: غزل 114)

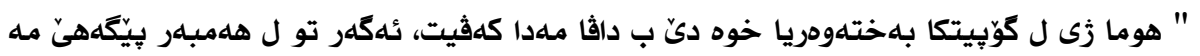
كوزهر بكهى"

$$
\begin{aligned}
& \text { محتزم دار دلهر كاين مكس قند برست] }
\end{aligned}
$$

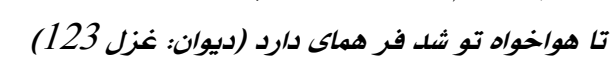

" قَهدريّ دلىّ من بزانه، زبهركو وهكى ميّشى شيرينى يا ليّقيَّن ته ستايش دكهت و لدهميّ بوويه

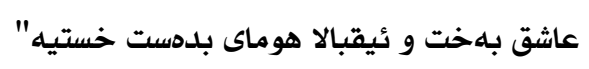

بالَّدهييّن سيمهرخ (عنقا) و هوما ل جهم مهلاييّ جزيرى و حافزىّ شيرازى ب رهمزيّن كَشتى هاتينه نيشاندان كو بهرى ثان عارفان ثئهو دوو ردمزه د جارجوفيّ ئهددبياتا عيرفانى يا زمانى فارسى ل جهم سلنايى و شيّخ عهتار(منطق الطير:32) و جلال الدين روّمى (كليات شمس: غزل 145 ) هاتينه بكار برن.

\section{4 هودهود}

تهيرهكه ل جهيّن دهشت و كَرو جيايان هليه ب كوردى ب جهند ناثان تئ ناسكرن ودكى:

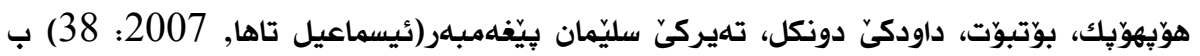
زمانى عهرهبى هلمان هودهوده، د ئهدبياتا تهسهوفيدا ودكى رهمزيّ مزرده، مزكينى و خوّش خلبهرى و قاسدى عشقى هاتيه نيشادان . د ديوانا جزيريدا، كو ب كشتى ب سيمبولى خوّش خهبهرى، مزكينى و قاسد بكار بريه ، لسهر وى

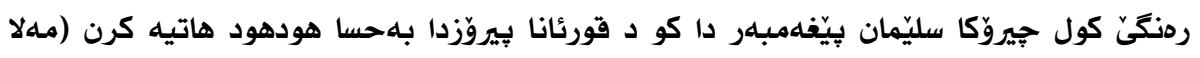


مهححمهد شهلماشى:1378،237)، مهلايى جزيرى 9 جاران هودهود د هلالبهستيّن خودا بكار بريه و ومكى دبيّزَيْ:

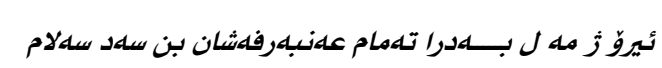

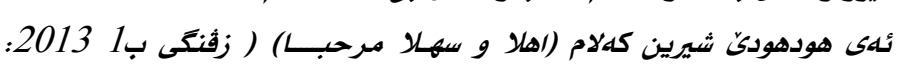
Z115

جزيرى لقر هودهود ودكى قاسد و شارهزا ب سيمبوّل كريه، بوّ كَهاندنا بِهياما عهشق و داخوازا

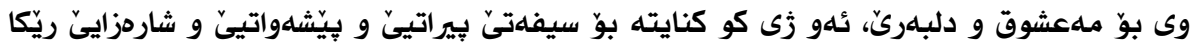
راستيى ، يان ئهو واسته يى سالكى دكَهينته ئارمانج (تحسين ئيبراهيم: 97، 2018)، نهخاسم كو د برتوكا (منطق الطير) دا شيّخ عدتتار رهمزيّ ريّزانى و بِيّشهواتييا كاروانى تهوالان بوّا سهفهر بلهر ب حهفيقهتا خوه ددهته هودهود (فريدالدين عهتتار: 31 )، ودكى دبيّزى:

$$
\begin{aligned}
& \text { مرحبا اى هلدهل هادى شلده }
\end{aligned}
$$

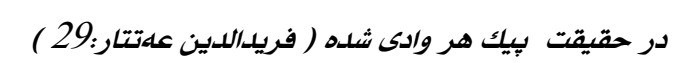

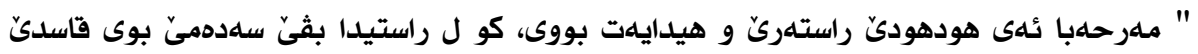

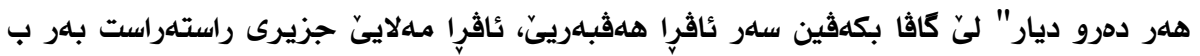
حافزيّ شيرازييه ودكى نُهو زى دبيّزى:

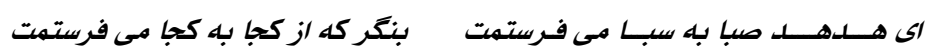

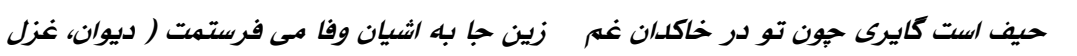

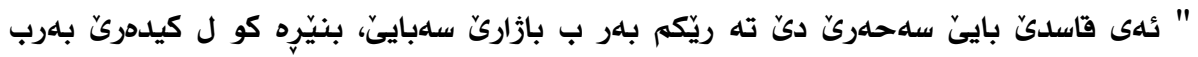

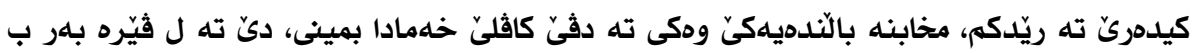
هيّلينا وهفايا دلبهريّ ريّكهم".

مهلايئ جزيرى د قوناغهكا بزاڤا خوه يا روحى دا هودهود ب سيمبول كريه، ودكى كو ل مالكا ئهولى يا سلريدا دياره د ردوشا ئامادهاريدايه، بوّ ريّكرنا هودهود ب قاسلدى، بوّ كَهياندنا بهياما

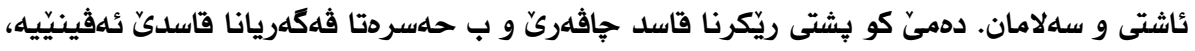

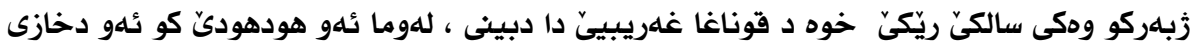
قاسلدى و واستتهيى بكهت، دڤيّت خوّش تهبع و نازك ودكى نهرما باييّ سهحهريّ (نهسيم) بيت وهكى كو دبيّزَى:

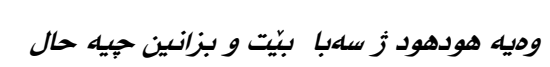

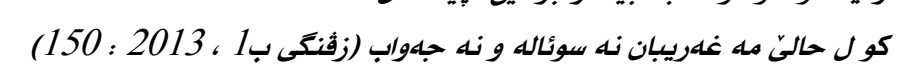




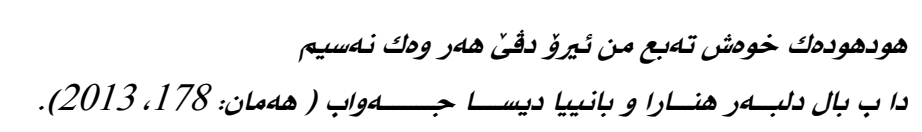

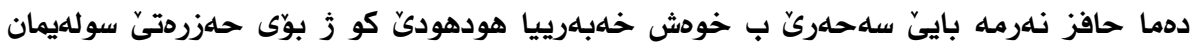

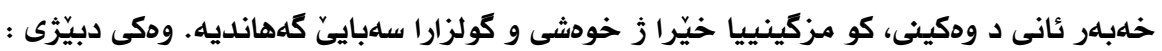
صبا خوش خبرى هلهدل سليمان است

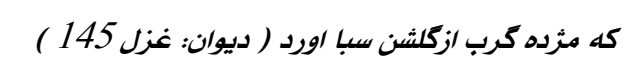

مهلايى جزيرى دهما دكههيته قوناغهكا ديتر يا روحى دكارين بيّزين قوناغا (معرفت الله )، هلست ب تلناهيا تهمام دكهت، نُهو زى ب سوياسكوزارى زمهعشوق كو خهبهردار بوويه ز ثالييى

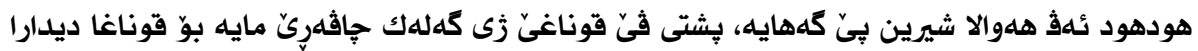

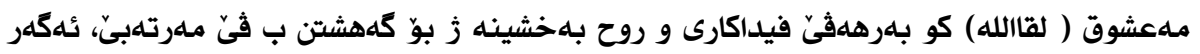

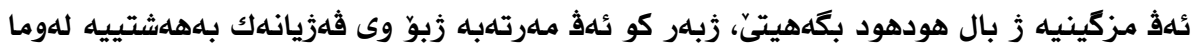
هلووالا هودهود ب رهمزيّ قاسد مزكينى و بههلشتا غهيبى زانييه، وهكى دبيّزَيّ:

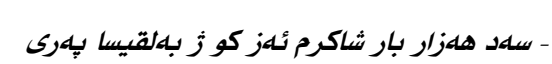

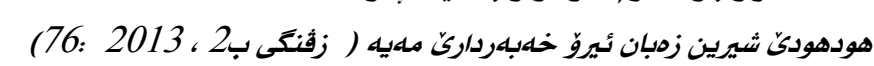

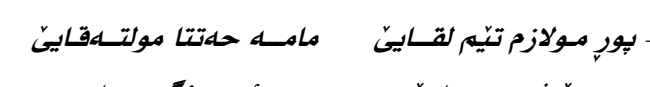

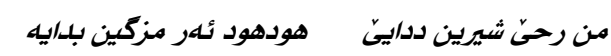

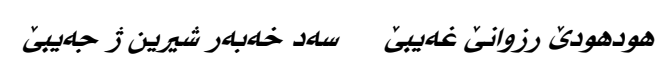

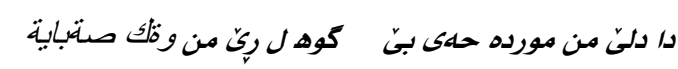

$$
\begin{aligned}
& \text { (100699: هتمان(2013) }
\end{aligned}
$$

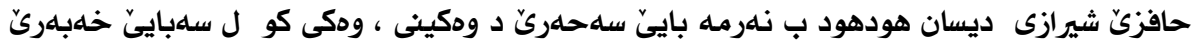
خوهش كههانديه حلزرهتى سولليمان، كو خوه د رهوشهك تهنا و ئارام دا ب سلددما مزكينييا خوهش دبينى وهكى دبيّزى: مثرده ایى دل كه دكر باد صبا باز امل

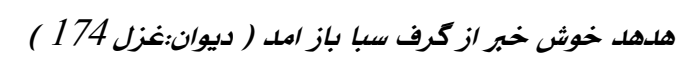

مهلاييّ جزيرى ب رهنكَكى كشتى (9) جاران سيمبوّلا هودهود د هلبهستيّن خوه دا بكار برييه، هلروهها حافزى شيرازى كو 4 جاران هودهود وهكى رهمز د ديوانا ويدا تيّته ديتن، كو هلردوو ب هلمان رهمزيلهتا داستانا حهزرهتى سولهيمان بكار برينه، هلرجهند مهلايى جزيرى ل داويدا پرسا 
رهمزا هودهود ثالا دكهت و ب روونى دبيّزى كو ئهثه سلربورا هودهوديّ داستانهك مهجازى و سيمبوّلييه سهخملراتى رازا هلقيقهتى ، بهلكى قاسد تهنىّ نيلهاملكه ودكى نهرمه بايىّ سهحهريّ تيّكلى خيالىّ دبى، وهكى دبيّزَى:

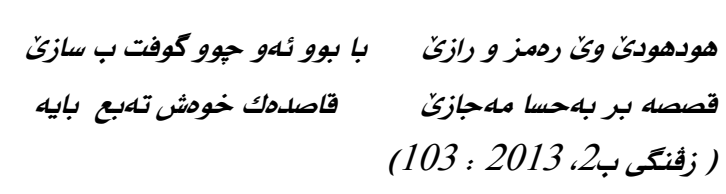

4.4 كبك( كهو)

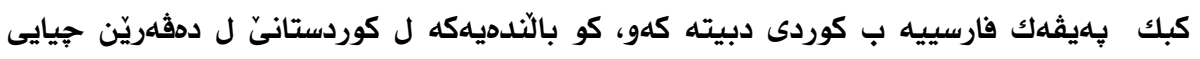
مشهنه و ب سروشتى خوه زى تهوالهكى جياييه، د نئهدبياتا عيرفانيدا ودكى سيمبوّل هاتييه بكار

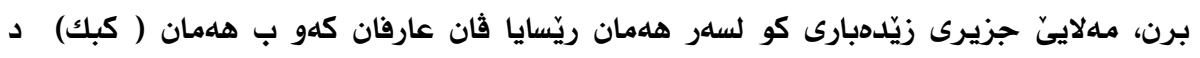
هلبلهستيّن خوهدا ودكى رهمزيّ ناز و دهلالى و عاشقى كَوهلران بكار برييه ، ليّ زبهر كو نئهو

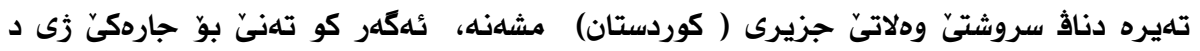
هللبهستيّن خوهدا بكار بريه، لى ب تايببلتملندييهك كلتورى، سروشتى و جثاكى نيشاندايه، كو

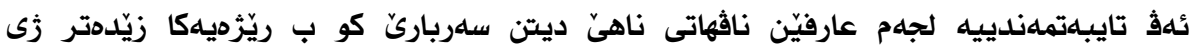
بكاربربن. وهىى كو جزيرى دبيّزى: ئهو كهبكى خهرامان كو د كوّزيّ ل قهبوّ هات شاهينيّ قهزايَّ ب تهغافول ز خوه را كرت (زفنكى ب1 ، 2013 : 213) تلهنى ب بكار برنا بهيڤا (كوّز) مهلايى جزيرى ب شارهزايى و هوورى تايبهتمهندييا سروشتى و

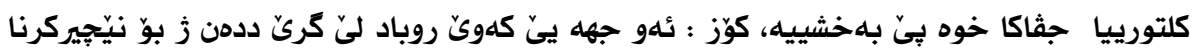
كهوا (محمدامين دوّسكى: 247،2007)، كو د كلتوريّ كورددوارى يهك ز ريّكيّن راث كرنا كهوان

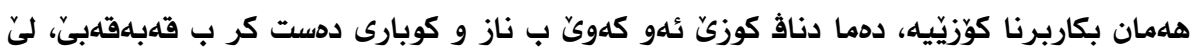
غافل ل بلنداهى كهفته ناثٌ ينجيّن شاهينى قهدهريّ. حافزيّ شيرازى 3 جاران سيمبوّلا (كبك ) د ديوانا خودا وهكى ردمزيّ غرور و غفلهت ونازدارى بكار برييه ودكى دبيّرَى: كه ز سرينـ ان قهقه كبك خرامين قهان غافل بود (ديوان: غزل 207) 
كلو يك زوان تهواليّن سلردكييه كو د (منطق الطير) يا فريدالدين علتتار دا ودكى عاشقى جِيا و كان و كَوهلهران هاتييه رهمزاندن، ودكى دبيّزَى:

$$
\begin{aligned}
& \text { كبك بس خرم و خرامان در رسيد سركش و سرمست از كان در رسيد }
\end{aligned}
$$

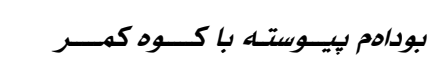

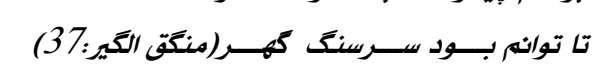

"كهو ب دلخوشى و نازداريهك تهمامفه ب سلرمهستى و سلركيّشيڤه كَها و كَّوت: بوونا من

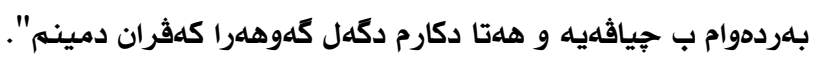
ب شروڤهيهكا عيرفانى مهرهما مهلايى جزيرى و حافزيّ شيرازى ز سيمبوّلا كهويّ ( كبك) هلمان

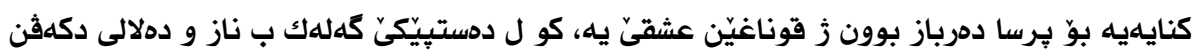

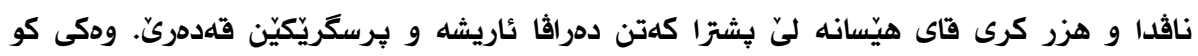
هلردوو دبيّزن:

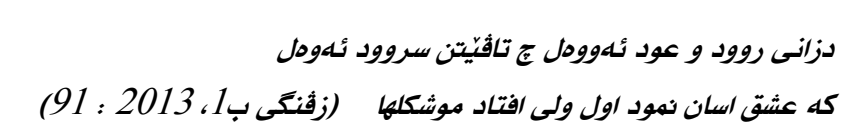

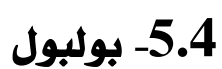

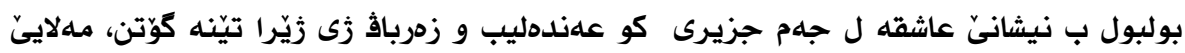
جزيرى 32 جاران د هلبلهستيّن خوهدا وهكى رهمز و نيشان بكار برينه، زيّدهبارى كو بولبول

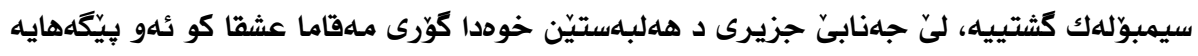

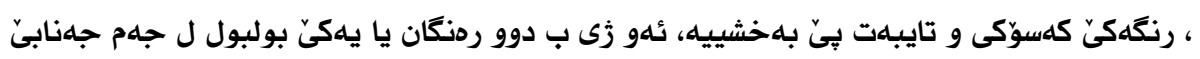

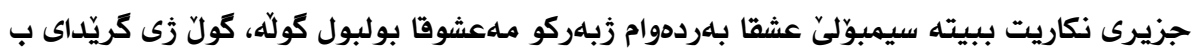
وهرز و دهمانه ودكى دبيّزى:

$$
\begin{aligned}
& \text { بولبول و بهروانه نـهو فهصل و دمدن] }
\end{aligned}
$$

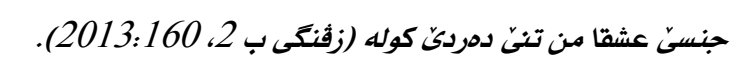

يا دوويان كَولّيّن كو مهعشوقيّن بولبولن ب هزمارن وكَلهكن بولبول عاشقى هلموو كَولَّانه، نكاريت ببيته رهمزيّ عشقا يلهكتاى وهكى دبيّزى: بولبولان صهد كول د جافن جاق لل صهد كول دى دكن]

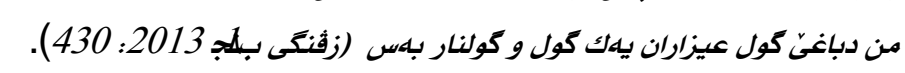


تايبهتمهندييا كو سليداييّ جزيرى ل رهمزييهتا بولبولى ئاثا دكهت و ل ويّ رهمزييهتا كشتى دهرباسى سيمبوّلهك كهووّكى و تايبهت يا كَرِّداى ب پِلهيا مهعريفى و فهلسهفييا عيرفانى يا خوه

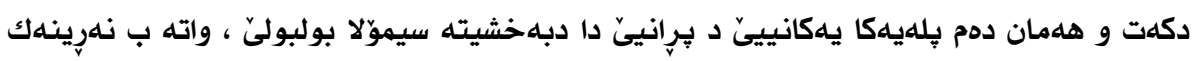

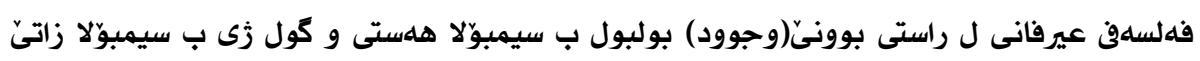

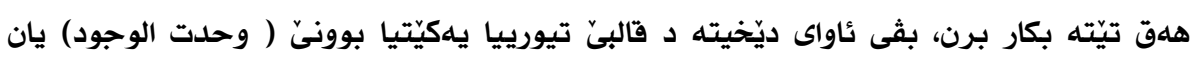

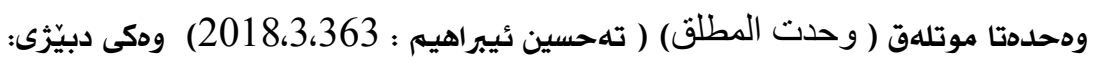

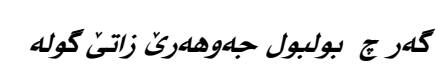

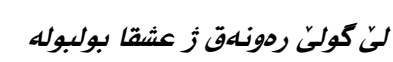

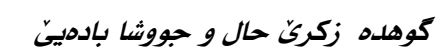

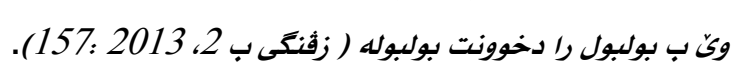

حافزي شيرازى بقاسى 59 جاران بهليثا بولبول د هلبلهستيّن خوددا بكار برييه، كو بكشتى ودكى سيمبوّلا عاشق بكار برييه، خوه د حالىّ بولبوليّدا ب كوثان و نالين ديتيه، لىّ دثان 59 حاران ل حالهتئ سيمبوّلا فهنا بوون د مهقاما عشقيّدا بكار برييه ودكى نموونه دبيّزَّى :

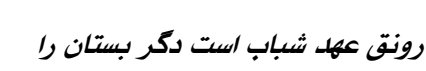

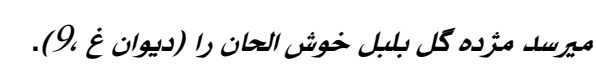

"جارهك دى وهرز و جوانى و رهونهقا باغ و بيستانه، مزكينييا بشكفتنا كولى دكههيته بلبلى

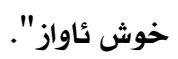

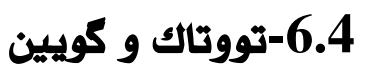

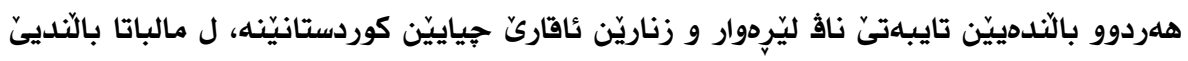

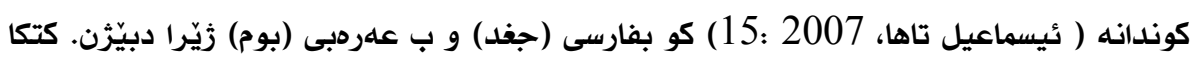

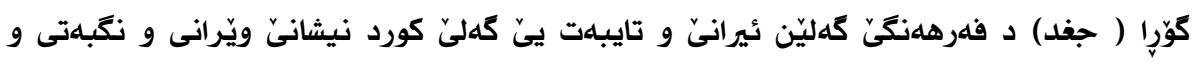

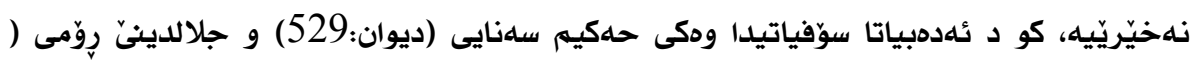
غزلييات: غ 78 ) ب ههمان رهمزيّ ويّرانى و نكَبلتى هاتييه. ئهد دوو ناشه زبهر كو كورمانجينه و د ئهدبياتا فارسى يا عيرفانى دا ناهيّن ديتن، ل كَور تايبهتمهندييا سروشتى و ئاوازا ڤان دوو تلهوالان مهلايى جزيرى ب سيمبولىّ ناليين و جوداهييا عشقى بكار برينه ، بقى جهنديّ جزيرى

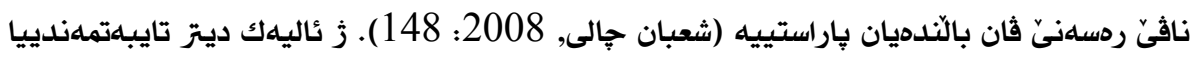
كلتورى و سروشتى و جفاكى د رهمزييهتا توتاك وكويينيّ دا بهرجلهسته كرييه، ل هلمان دهم ئهو بالنده ل واريّ كهلهخى ثه كَلهك ودكهلهن، ليّ هلريهك خودى تايبهتمهندييا خوه يا سروشتييه. 


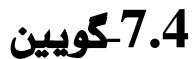

كَويين كو ناثهك كورمانجييه ل هنهك دهران كَولى كَولى ، كَويينا رِيّلان و كونده زيْوه زى زيّرِا دبيّزْن، ب علردبى الخبل؛بومه سمرا و نافيّ زانستى Strix aluco (ئيسماعيل تاها, 2007:

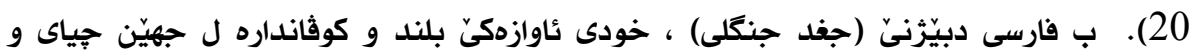

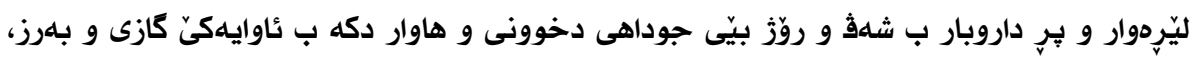

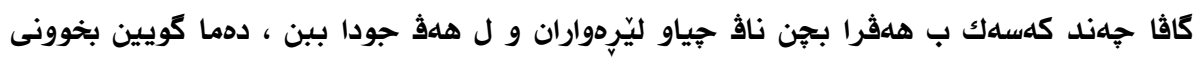

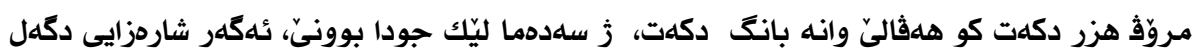

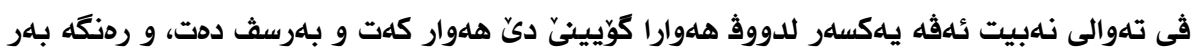

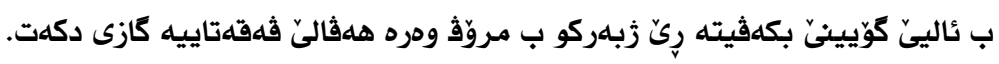
مهلايَّ جزيرى دمما دبينى كو عشقا وى عشقهك بِر كَران و سوّزناك و بهرددوام و زيندييه ، واته كَهايه بالاترين مهقاما (بقاو الله) هلوجلدارى كالين و نالينهكا بهرددوام و هلوارهك و كوّانانها بلهرز و بلند و زيندييه، للهوما بِيّدفى سيبموّلهك و وهكاندنهك كونجاى تر ل بولبول و بِهروانه دكَهريّ، زبهركو نالين و فيداكارييا وان دممكى و وهرزينه و بهرددوام نيه وهكى كو دبيّزىى:

\section{بولبول و بهروانه نئهو فهصل و دمصن]}

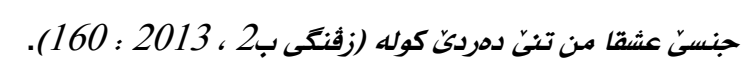

ل زَيّر باندورا فلكلورا كورمانجى و سروشتى كوردستانيّ مهلايى جزيرى كَّيين ب كَونجاوتر زانييه كو ببيته رهمزا عشقا بهردموام و زيندى، زبهركو سروشتى ئاواز وخووندنا بهرددواما ب شهو و روّز هلروهها ل هلر جار وهرزان ، يا هلوار و كوقان و نالينا كَويينى باشتز ز نالينا بولبولىّ

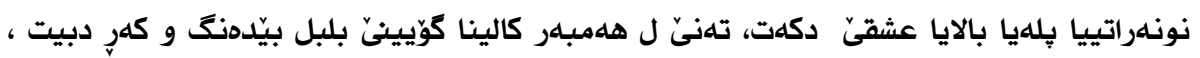
جزيرى د هلبلهستيّن خودا بِينج جاران كَويين بكار بريه ودكى دبيّرىى:

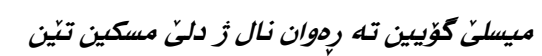

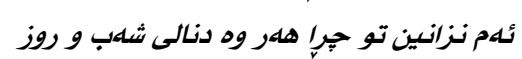

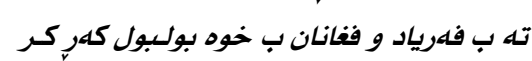

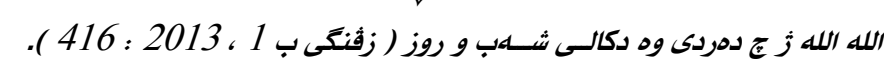

سهحهركه عهندوليب مهستن زبيّينا وهرد و بشكوزران]

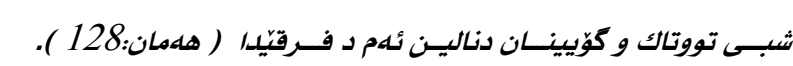




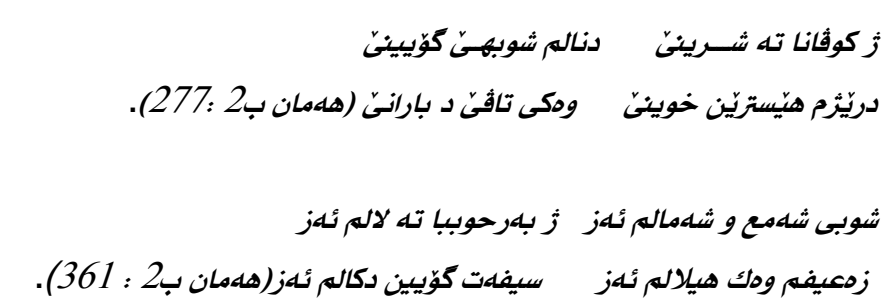

ديسان د بلندترين مهقاما سلوكيّدا ملهلايى جزيرى كَّيّينى دكهته سيمبوّلا مدقاما بهقايَّ ، واته

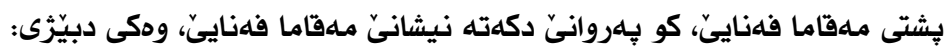

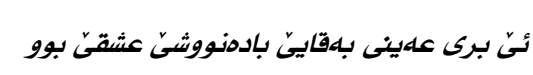

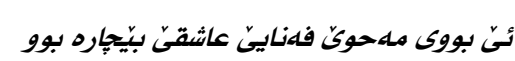

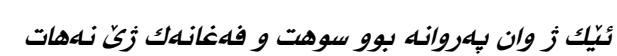

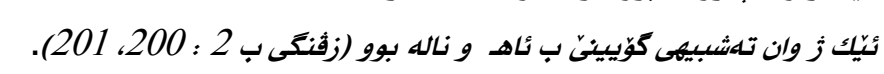

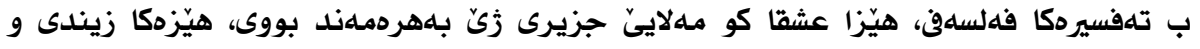

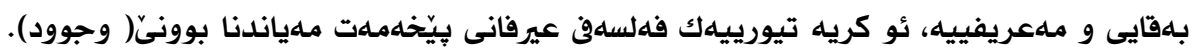

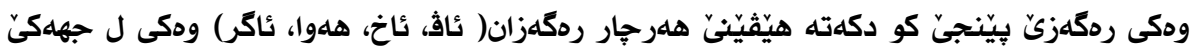

\section{مه جبهوهار عونصورهك خامس نوما ئيرو د تالع دالح

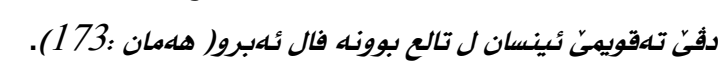

بِهروانه زبهر كو لجهم مهلايى جزيرى سيمبوّلا عشقهك بيّجاره و دممكييه ، ددمى كو كَّويين سيمبوّلا عشقا بهرددوام و زيندييه، ليّرددا ئاهـ و نالينيّن كَوّيينى كنايهيه زبوّ وكّ عشقى كو بوويه بنهمايىّ هلبوونىّ و مهعريفهيىّ بِيّخهم بزفين بلهر ب كهمالىّ .

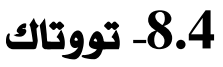

ناقهكى كورمانجييه ل هندهك دهران دبيّزَنى تووك يان تاقتاقى بوّر، ب عهرهبى الثبج المخطط،

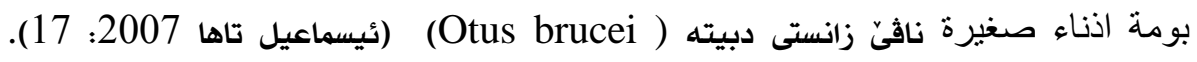
مهلايىّ جزيرى بالندهيى تووتاك وهكى كَّويين ب سيمبوّلى عاشقى كوّاندار كو بهرددوام د ناليندايه نيشاندايه، د هلبلهستيّن جزيرى 2 جاران ئامازه كريه ب نافيّ تووتاك ودكى دبيّزىى: سهحهركه عهندهليب مهستن زبهنا وهرد و بشكوزّان شبى تووتاك و كَّيينان دناليـن ئهم د فهرقيّدا (زفنكى ب 1، 2013: 128). 
جزيرى لسهر بنكَها تايبلتماندييا خوهزايى و كلتوريّ خوه ئاوازيّ تووتاكيّ كو بلهردوام شهفيّ

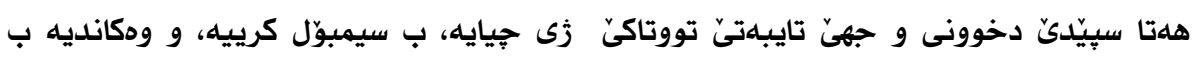

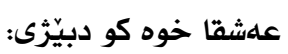

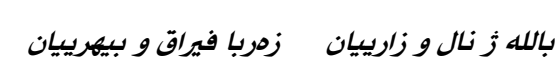

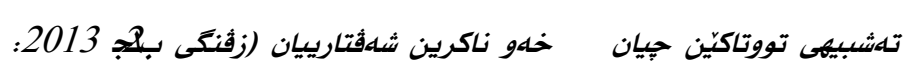

$\nabla \longdiv { 3 9 6 }$

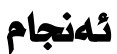

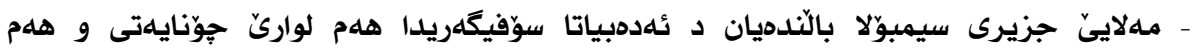

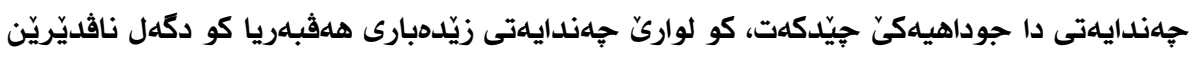

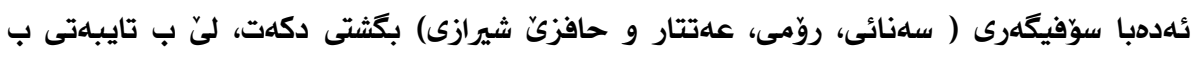

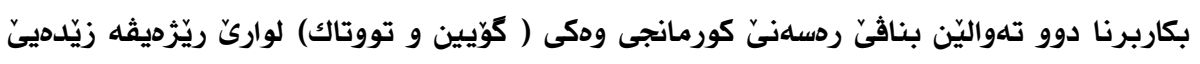

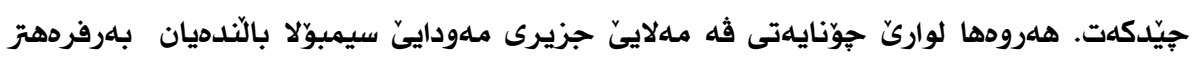

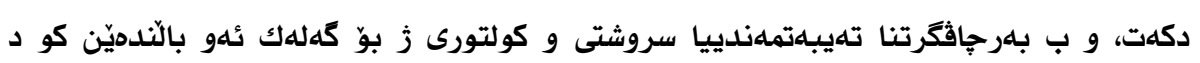

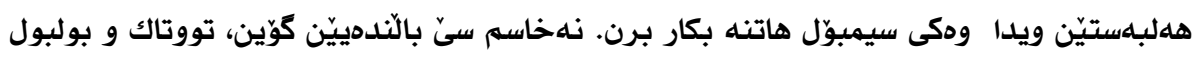

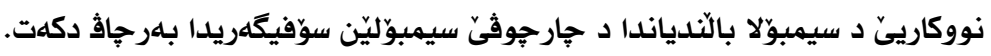
- هندهك ز سيمبوّلان كهسوّىى يان تايبهتن ب هلبلهستقانهكي يان نفيسهرهكى سيمبوّلثانن، جورهك دى ز سيمبوّلان كَتينه، كو كَلهك ز نفيسهر و شاعريّن سيمبوّلقان وهكى بنهما

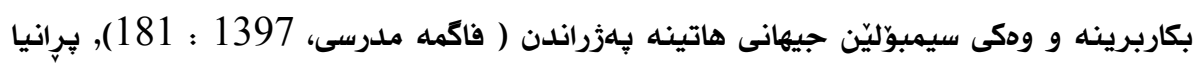

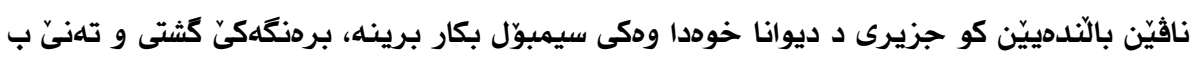
هلمان زمانى كو سوّفيّين فارس ودكى سلنائى غلزنهلوى ، جلاالدين روّمى، فريدالدين علتتار و

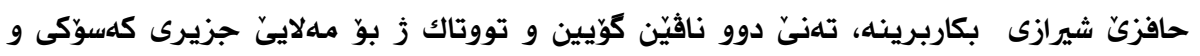
تايبـلن - ريّرَّيا بالندهييّن كو د ديوانا مهلايى جزيريدا ودكى سيمبوّل هاتينه بكار برن زيّدهى 30 سى

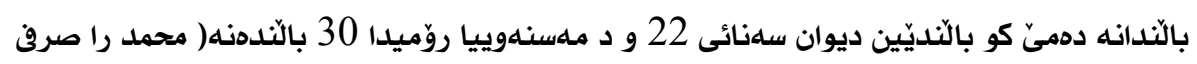


- جوداهيدكا كرينگ كو مـلاييّ جزيرى د شيّوازيّ بكاربرنا سيمبوّلا بالنديان نيشان دده هلمان روويئ ئهريّنى و جوانييا وان بالندديانه كو ودكى سيمبوّل د هلبهستيّن خوه دا بكار برينه فهلسهفهيا حوسن و جهماليّ د علهقا بوونيّدا بهرجلهته دكهت.

\section{جاڤكانى}

كوردى:

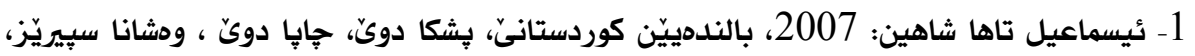
دهوّك.

2 - عيماد وديسى خالد:2004،جلهفهنگ د هوزانا ريالستيكا كوردى دا، وهشانا سييريز، هلوليّر. 3- كَرددنهيا كَهوهلرى:2013 ، شهرحا ديوانا مهلاييّ جزيرى، مهلا ئهحملديّ زفنكى،ئاماددكرن و وهركهر ز علردبى ئهمين نهوروزى، وهشانا ئاڤيّستا، جابِا يهكهم، ستانبول.

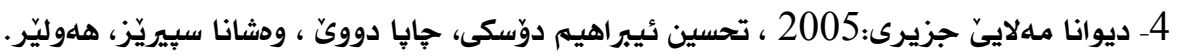

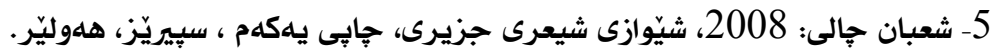

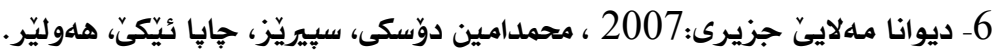
7- ديوانى عارف ربانى شيّخ احمدى جزيرى: 1361 هلتاوى، شهرحى هلزار،انتشارات سروش. 8- مـلا موحهمددى شهلماشى: 1378ش ، زيانى بِيّخهمبهران، جإِى 7 ،بلاوكراوهى كوردستان، سنه.

9- شهرحا ديوانا مهلايّى جزيرى: 2018 ، شروڤهيا تهحسين ئيبراهيم دوّسكى، جإِ ئيّكىّ، وهشانا

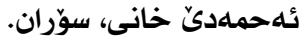
فارسي:

10 - اريك فروم: 1349 ش ،زبان از ياد رفته، ترجمه ابراهيم امانت، انتشارات مرواريد، تهران . 11- تقى بֶورنامداريان: 1364ش ، داستان بِيامبران در كليات سمس، موسسه مطالعات و تحقيقات فرهنكى، تهران. 12- جلال ستارى: ، اساس نسخه قاسم غنى و محمد قزوينى،كتابخانه جِلييا، جاب اول، تهران. 
13ـ ديوان كامل شمس تبريزى: 1371ش، مولانا جلال الدين محمد مولوى، مصحح: بديعالزمان فروزانفر، انتشارات نكاه، جֶاب اول، تهران.

14ـ منطق الطير. فريدالدين عطار، كتابخانه اميد ايران،wwww.irebooks.com 15-. حديقهالحديقه: 1382 ، ابوالمجد مجدود سنايى، تصحيح دكتر مريم حسينى، جاب اوّل، تهران: مركز نشر دانشكاهى.

16ـ فاطمة مدرسى:1397 مفاهيه رمزى، تمييلى و نمادين برندكان در رباعيات و قصايد عطار، نسيم شرق، مجله مطالعاتي ايرانشناسى زبان و ادبيات فارسى، شماره 9. 17- د. محمد رضا نصر اصفهانى - حافظ حاتمى: پايز 1388ش، رمز و رمزگَراى با تكيه بر ادبيات منظوم عرفانى، فصلنامه ادبيات عرفانى و اسطورة شناختى، سال 5 شماره 16 . 18- د. محمد رضا صرفى : زمستان1386 ، نماد برندكان در مثثوي، فصلنامه برزوهشهاى ادبى

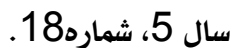

19- زان و الن گَريران شواليه. فرهنگ نمادها، ترجمه سودابه فضايلى، تهران ، 1378.

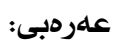

20- صافييه زفنكى: 2017، جماليات الدلالات الصوفيه في المعجم اللغوى لديوان الجزيرى، وهشانا

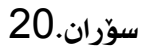

22- عبدالسلام جزيرى:2004, شرح ديوان الشيخ الجزيرى, مطبعة التزبيه, اربيل. مالِيهِيْن ئمنترنيتّى:

22-https://en.wiktionary.org/wiki/symbol

23-https://www.etymonline.com/word/symbol

\section{Çavkanî}

Celaleldîn Romî, M. (1371). Diwanê Kamilê Şemsê Tebrîẑ̂, Museheh: Fîruzanfer, Weşanên Nêgah,Tehran.

Cizîrî, A. (2004). Şerih Dîwan Alcizîrî, Metbe`e Alterebiye, Erbîl.

Çalî, Ş. (2008). Şêwazî Şî̀rî Cizîrî, Çapî Yekam,Weşanên Spîrêz, Hewlêr.

Doskî, M. (2007). Dîwana Melayê Cizîrî, Çapa Yekê, Weşanên Sîrêz, Hewlêr. 
Doskî, T.E. (2005). Dîwana Melayê Cizîrî, Çapa Duyem, Weşanên Spîrêz, Hewlêr.

Doskî, T.E. (2018). Şerha Dîwana Melayê Cizîrî, Çapa Yekem W. Ehmedê Xanî, Soran.

Etar, F. (Bê Tarîx ). Mentiqet Eltteyr, Kitabxanê Omîdê Îran.www.irebooks.com.

From, Erîk. ( 1349). Zebanê Ez Yad Teftê, Wer. Ebrahîmê Amanet, Murwarîd, Teharan.

Hejar. (1361). Dîwanî Rebbanî Şeyx Ehmedê Cizîrî, Siruş.

Imad, W. X. ( 2004). Ceveng di Hozana Reyalîstîka Kurdî da, Weşana Spîrêz, Hewlêr.

Îsmayîl ,T. Ş. (2007). Balindeyên Kurdistanê, Pişka Duyem, Çapa Duyem, Weşanên Spîrêz, Duhok.

Mudersî , F. (1397). "Mefahîmê remzî û temsîlî û nemadînê perendgan der ruba yat û qessaydê Etar, Nesîmê Şerq", Mecelle Muttali atî Îranşinasîyê Zeban $\hat{u}$ Edebiyatê Farisî, j. 9.

Nesir Esfehanî, M- Hatemî, H. (Payîzê 1388). "Remiz û remizgerayî ba tekîyê ber edebiytê menzum îrfanî”, Feslnamê Edebiyatê Îrfnî û Estture Şinaxtî, sal 5, j.16.

Pornamdaryan, T.(1364). Dastanê Peyamberan der Kuliyatê Şemis, Tehran.

Qenî,Q.- Qezvînî, M. (1369). Dîwanê Hafiz, Çapê Ewel, Çelîpa, Tehran.

Şelmaşî, M. (1378). Jiyanî Pêxemberan, Çapa Heftem, Sine.

Senayî, A.M. (1382). Hedîqe Elhedîqe, Teshîh D. Meryamê Huseynî, Çapê Ewel, N. Danişgahî, Tehran.

Serfî,M. (Zimistanê 1386). "Nemadê Perendigan der Mesnewî", Feslnamê Pijuhişhayê Edebî, sal 5, j.18

Setarî, C. (1372). Medxelî Ber Remiz Şinasîyê Irfanî, N.Merkez, Tehran.

Şwaliyê, J.A.G. (1378). Ferhengê Nemadha, Wer. Sudabê Fezayîlî, Tehran.

Zivîngî Safiye. (2017). Camaliyat Eldlalat Elssufiye fì Elmu'cem Elluxewiye Lidîwan Alcizîrî̀, Weşanên Soran.

Zivingî, E. (2013 ). Gerdeneya Gewherî:Şerha Dîwana Melayê Cizîrî, Amadekarî û Wergera ji arebî Emîn Narozî, Weşanên Avesta, Stembol. 
https://en.wiktionary.org/wiki/symbol

https://www.etymonline.com/word/symbol 